\title{
Corrigendum: Frequency of Microplastics in Mesopelagic Fishes from the Northwest Atlantic
}

\author{
Alina M. Wieczorek ${ }^{1,2 *}$, Liam Morrison ${ }^{1}$, Peter L. Croot ${ }^{1,3}$, A. Louise Allcock ${ }^{2}$, \\ Eoin MacLoughlin ${ }^{2}$, Olivier Savard ${ }^{4}$, Hannah Brownlow ${ }^{2}$ and Thomas K. Doyle ${ }^{2,5}$ \\ ${ }^{1}$ Earth and Ocean Sciences and Ryan Institute, School of Natural Sciences, National University of Ireland Galway, Galway, \\ Ireland, ${ }^{2}$ Zoology and Ryan Institute, School of Natural Sciences, National University of Ireland Galway, Galway, Ireland, ${ }^{3}$ Irish \\ Centre for Research in Applied Geoscience, Earth and Ocean Sciences, School of Natural Sciences, National University of \\ Ireland Galway, Galway, Ireland, ${ }^{4}$ Perkin Elmer, Beaconsfield, United Kingdom, ${ }^{5}$ School of Biological, Earth and \\ Environmental Sciences, MaREI Centre, Environmental Research Institute, University College Cork, Cork, Ireland
}

Keywords: myctophids, marine litter, micro-FTIR, fibres, eddy, deep sea, biogeochemical cycling, carbon sequestration

\section{A corrigendum on}

Frequency of Microplastics in Mesopelagic Fishes from the Northwest Atlantic by Wieczorek, A. M., Morrison, L., Croot, P. L., Allcock, A. L., MacLoughlin, E., Savard, O., et al. (2018). Front. Mar. Sci. 5:39. doi: 10.3389/fmars.2018.00039

\section{OPEN ACCESS}

Edited and reviewed by: Angel Borja Centro Tecnológico Experto en Innovación Marina y Alimentaria

(AZTI), Spain

*Correspondence:

Alina M. Wieczorek

alina.wieczorek@nuigalway.ie

Specialty section:

This article was submitted to Marine Pollution

a section of the journa

Frontiers in Marine Science

Received: 12 March 2018

Accepted: 26 March 2018

Published: 01 May 2018

Citation:

Wieczorek AM, Morrison L, Croot PL, Allcock AL, MacLoughlin E, Savard O,

Brownlow H and Doyle TK (2018) Corrigendum: Frequency of

Microplastics in Mesopelagic Fishes from the Northwest Atlantic.

Front. Mar. Sci. 5:127.

doi: 10.3389/fmars.2018.00127
1: In paragraph 2 of the Discussion section the retracted article by Lönnstedt and Eklöv (2016) was mistakenly cited in the manuscript. While the authors were aware of the retraction it was accidentally introduced. It should be replaced by Carpenter et al. (1972) who also showed ingestion of microplastics by fish larvae.

In the original article, we incorrectly cited Lönnstedt and Eklöv (2016), as follows:

"Indeed the most common prey of mesopelagic fish are copepods, euphausiids, amphipods, larvae, and decapods and all have been reported to ingest microplastics (Setälä et al., 2014; Desforges and Ross, 2015; Lönnstedt and Eklöv, 2016)."

This reference should be replaced with the following:

"Indeed the most common prey of mesopelagic fish are copepods, euphausiids, amphipods, larvae, and decapods and all have been reported to ingest microplastics (Carpenter et al., 1972; Setälä et al., 2014; Desforges and Ross, 2015).”

2: In the sixth sentence of the abstract it states that samples were collected $1,200 \mathrm{~km}$ due west of Newfoundland. This should have stated "east" of Newfoundland. The authors very much apologize for these mistakes. These errors do not change the scientific conclusions of the article in any way.

The original article has been updated.

\section{REFERENCES}

Carpenter, E. J., Anderson, S. J., Harvey, G. R., Miklas, H. P., and Peck, B. B. (1972). Polystyrene Spherules in Coastal Waters. Science 178, 749-750. doi: 10.1126/science.178.4062.749

Desforges, J. P., and Ross, P. S. (2015). Ingestion of microplastics by zooplankton in the Northeast Pacific Ocean. Arch. Environ. Contam. Toxicol. 69, 320-330. doi: 10.1007/s00244-015-0172-5

Lönnstedt, O. M., and Eklöv, P. (2016). Environmentally relevant concentrations of microplastic particles influence larval fish ecology. Science 6290, 1213-1216. doi: 10.1126/science.aad8828

Setälä, O., Fleming-Lehtinen, V., and Lehtiniemi, M. (2014). Ingestion and transfer of microplastics in the planktonic food web. Environ. Pollut. 185, 77-83. doi: 10.1016/j.envpol.2013.10.013

Conflict of Interest Statement: The authors declare that the research was conducted in the absence of any commercial or financial relationships that could be construed as a potential conflict of interest.

Copyright $\odot 2018$ Wieczorek, Morrison, Croot, Allcock, MacLoughlin, Savard, Brownlow and Doyle. This is an open-access article distributed under the terms of the Creative Commons Attribution License (CC BY). The use, distribution or reproduction in other forums is permitted, provided the original author(s) and the copyright owner are credited and that the original publication in this journal is cited, in accordance with accepted academic practice. No use, distribution or reproduction is permitted which does not comply with these terms. 